\title{
EVALUATION OF DIFFERENT SOURCES AND LEVELS OF DIET DILUENTS ON BROILERS PERFORMANCE AND CARCASS QUALITY.
}

\author{
Hemat A. Abdel Magied ${ }^{1}$; Mona A. S. A. Mostafa ${ }^{2}$, M.A. ElMenawey ${ }^{3}$ \\ ${ }^{1}$ Dep. of Poul. Nut Res. Anim. Prod. Res. Inst., ARC, Dokki, Giza-12618, Egypt \\ 2 Dep. of Poul. Breeding Res, Anim. Prod. Res. Inst., ARC, Dokki, Giza-12618, Egypt \\ ${ }^{3}$ Animal production Dep., faculty of Agriculture, Cairo University, Giza, Egypt
}

(Received 16/7/2020, accepted 1/9/2020)

\section{SUMMARY}

$\mathrm{T}$

his study aimed to investigate the effect of wheat bran (WB) and sugar beet pulp (BP) low density feed ingredients sources on the broiler performance and carcass quality. Both WB and BP were evaluated using diet dilution (DD) technique with different levels. Two hundred and seventy unsexed one-day old Arbor Acres broiler chicks were randomly allocated to nine experimental treatments; each treatment contains three replicates of ten chicks each. Control was the $1^{\text {st }}$ treatment, the rest 8 treatments divided in to two main groups of DD first group (2, 3, 4 and 5 treatments) diluted with 2, 3, 4 and 5\% wheat bran (WB2, WB3, WB4 andWB5) from the control diets and second group (6, 7, 8 and 9 treatments) diluted with 2, 3,4 and 5\% sugar beet pulp (BP2, BP3, BP4 and BP5). The result indicated that, DD with WB significantly recorded the highest starter, finisher and overall body weight (BW) and body weight gain (BWG)and significantly improve feed conversion ratio (FCR). Levels of dilution affected significantly on BW and BWG during all phases. Among all treatments, WB5 showed the highest BW and BWG compared to other treatments. The best FCR significantly was recorded byWB5 compared to all treatments during finisher and overall period. Broilers fed DD with BP were significantly had higher dressing, breast, wing, and drumstick \% compared with WB. Increasing levels of DD reflected in increasing dressing\%. Using the higher level of DD (5\%) reflected in decreased the abdominal fat \%. The interaction between DD and their levels showed significantly different on all carcass parameters except edible parts. The broiler fed BP4 and WB5 recorded the highest dressing \% compared to all treatments. There was significant interaction between DD and levels in intestine length and index and tibia weight\%. Using DD with WB significantly reduced respiration rate (RR) compared $\mathrm{BP}$. However, levels had a significant effect on rectal temperature (RT) and blood oxygen $\left(\mathrm{O}_{2}\right)$. The effect of the interaction had impact beneficial effect on decreased RT and RR and increased $\mathrm{O}_{2}$. All treatments improve the relative economic efficiency (REE) of production except WB2and the highest one recorded by WB5. Dilution broiler diet with Wheat bran at 3, 4 and 5\% and sugar beet pulp at 2, 3 and $4 \%$ improve growth performance, carcass quality, intestine index, economic efficiency, feed coast and REE. Among examined levels the best results recorded by applying 5\% WB and 4\% $\mathrm{BP}$.

Keyword: broiler, wheat bran, beet pulp, performance, carcass.

\section{INTRODUCTION}

Constant improvement in nutrition and genetic selection, has led to a fast growth rate in modern broiler strains (Van Der Sluis, 1999). Unfortunately, this growth is accompanied by increased body fat deposition, high mortality and high incidence of metabolic diseases and skeletal disorders (Zubair and leeson, 1996). This situation most commonly occurs with broiler that consume feed ad libitum (Nir et al., 1996). However, the availability of feed ingredients at affordable cost is a key to successful poultry operations. Currently, one of the major challenges in poultry studies is to improve gut health by dietary modulation, especially during the early stages of life. dietary fiber has gained special attention due to its various beneficial effects on poultry (Shang et al., 2020). Increasing the structural components in the diet and manipulating the dietary fiber composition, has been shown to improve gut health, feed utilization and production efficiency and can alleviate enteric disease (Kheravii et al.,2018).

Dietary non-starch polysaccharides (NSP), namely insoluble NSP, which have been shown beneficial effects on gut health, litter quality and nutrient utilization, by increasing crop and gizzard activity, stimulating digestive enzyme production and enhancing bacterial fermentation in the hind gut (Kheravii et al., 2018).There is increasing evidence showing that moderate amounts of insoluble dietary fiber can 


\section{Abdel Magied et al.}

improve nutrient utilization by positively influencing the physiology of the gastrointestinal tract(Shang et al., 2020).

Wheat bran (WB), a byproduct of the milling process, is rich in insoluble fiber, consisting mainly arabinoxylans and, to a lesser extent, cellulose and $\beta$-glucans (Kamal-Eldin et al., 2009). The proximate analysis for WB according to RCFF (2001) is $87 \%$ dry matter, $15 \%$ crude protein, $1400 \mathrm{kcal} / \mathrm{kg}$ metabolic energy, $4 \%$ ethaline extract, $9.6 \%$ crude fiber, $12 \%$ ADF, $40 \%$ NDF, $2.7 \%$ Lingnine, 9.9\% Cellulose, 5.6\% Ash, 0.14\% Calcium, 1.2\% total phosphors, 0.60\% Available phosphors, $0.56 \%$ 1ysine, $0.20 \%$ methionine, $0.50 \%$ methionine+ cysteine, $0.54 \%$ threonine and $0.24 \%$ tryptophan.Also, NRC (1994) recorded the proximate analysis for $\mathrm{WB}, 88 \%$ dry mater, $1300 \mathrm{kcal} / \mathrm{kg}$ metabolic energy, $15.4 \%$ protein, 3 $\%$ ether extract, $11 \%$ crud fiber, $0.26 \%$ methionine, $0.32 \%$ cysteine, $0.61 \%$ lysine, $0.14 \%$ calcium, 1.15 $\%$ total phosphorus, $0.20 \%$ available phosphorus, $0.48 \mathrm{mg} / \mathrm{kg}$ biotin, $186 \mathrm{mg} / \mathrm{kg}$ niacin, $31 \mathrm{mg} / \mathrm{kg}$ pantothenic acid, $4.6 \mathrm{mg} / \mathrm{kg}$ riboflavin and $14 \mathrm{mg} / \mathrm{kg}$ vitamin $\mathrm{E}$. The WB has been shown to be involved in the regulation of gastrointestinal physiology such as gastric emptying time and intestinal transit rate, which may consequently influence digestive function (De Mora Ruiz-Roso, 2015). Besides, some studies demonstrated that WB plays an important role in metabolism(Liu et al., 2014), feed with high soluble fiber content and low degree of lignification is prone to bacterial degradation and therefore has great influence on bacterial metabolism and production of short-chain fatty acids (SCFAs), such as acetate, propionate, and butyrate (Nyman et al., 1990).In addition, arabinoxylan (AX) or arabinoxylo oligosaccharides (AXOS) derived from WB has been shown to improve gut health such as gut microbiota, which may in turn improve digestive traits (Akhtar et al., 2012). Dietary fiber supplementation $0.05 \%$ arabinoxylan-oligosaccharides in wheat-based broiler diets revealed that these AXOS boosted total tract wheat AX digestion in young broilers (Bautil et al.,2020). Also, Sahraei and Shariatmadari (2007) reported that increased feed intake and decreased body weight and body weight gain compared to control when diluted broiler diet with $28 \%$ wheat bran (wt:wt). On the other hand, Shang et al., (2020) observed that replacing $30 \mathrm{~g} \mathrm{WB} / \mathrm{kg}$ diet enhanced nutrient digestibility by improving antioxidant status, gizzard development, intestinal digestive enzyme activities and morphology of broilers and concluded that moderate amounts of insoluble dietary fiber can improve nutrient utilization by positively influencing the physiology of the gastrointestinal tract.

Sugar beet pulp (BP) is the solid residue that remains after sugar extracted from sugar beetroots; hightemperature drying of sugar beet increases the concentration of nutrients by 4-5 times compared to the initial raw materials. One kilogram of dry pulp contains 9.7- 11.2 MJ metabolic energy and $102.7 \mathrm{~g}$ of protein. Rich in nitrogen-free extractive substances $(70.6 \%)$, relatively high in calcium, sodium, magnesium and trace elements (Koschayev et al., 2019). Dried BP, has been used as a partial source of energy in the rations of broiler diets, the effect of BP levels in starter period showed that BP level at $1 \%$ was significant on broiler performance (Gonzalez Alvarado et al., 2010). This result agrees with Mateos et al., (2002) who reported that the inclusion of fiber in the diet might benefit nutrient digestibility and growth performance in broilers. Moreover, Gonzalez Alvarado et al., (2007 and 2010) reported that young broiler chicks require minimal amount of fiber in the diet. Their results showed that data obtained during 11-24 days (grower period) indicated that BP level at 3\% was the best compared with 3\% oat hulls and control. These results supported the findings of Jimenez-Moreno et al., (2009 a and b) showed that using dietary $3 \% \mathrm{BP}$ recorded the best growth performance compared to the control during period from 125 days. Also, the same results were observed during finisher and total periods. These results agree with Koschayev et al., (2019) who replaced 4\% of chicken diet with dry BP during 21-41 days of age, and reported positive impact on their productivity, the quality of meat products and economics of production.

Therefore, this study aimed to evaluate using low density feed ingredients sources wheat bran and sugar beet pulp on broiler performance and carcass quality when used diet dilution technique at four levels 2, 3, 4 and 5\% (wt:wt) of control standard broiler diets.

\section{MATERIALS AND METHODS}

\section{Experimental diets and birds:}

The experiment was undertaken at Poultry Research Farm, Faculty of Agriculture, Cairo university, Egypt during March and April months. Two hundred and seventy unsexed one-day old Arbor Acres broiler chicks were randomly allocated in nine experimental treatments; each treatment contains three replicates of ten chicks each. Control was the $1^{\text {st }}$ treatment, the rest 8 treatments divided to two groups of diet dilution (DD) the first group included 2, 3, 4, 5 treatments diluted(wt:wt) with 2, 3, 4 and 5\% wheat bran (WB2, 
WB3, WB4 and WB5) from the control diets and the second group included treatments 6 to 9 diluted with 2, 3,4 and $5 \%$ sugar beet pulp (BP2, BP3, BP4 and BP5), the design was observed in Table (1).

Table (1): The experimental design

\begin{tabular}{lccccccccc}
\hline & \multicolumn{8}{c}{ Treatment } \\
\cline { 2 - 10 } Ingredient & \multicolumn{1}{c}{ Wheat bran } & \multicolumn{7}{c}{ Diet dilution (DD) } \\
\cline { 2 - 10 } & \multicolumn{1}{c}{ Control } & \multicolumn{1}{c}{ Sugar beet pulp } \\
\cline { 2 - 10 } & 1 & 2 & 3 & 4 & 5 & 6 & 7 & 8 & 9 \\
\hline Control diet & $100 \%$ & $98 \%$ & $97 \%$ & $96 \%$ & $95 \%$ & $98 \%$ & $97 \%$ & $96 \%$ & $95 \%$ \\
Wheat bran & - & $2 \%$ & $3 \%$ & $4 \%$ & $5 \%$ & - & - & - & - \\
Sugar beet pulp & - & - & - & - & - & $2 \%$ & $3 \%$ & $4 \%$ & $5 \%$ \\
\hline
\end{tabular}

The approximate analysis of fiber fraction for dilution sources (wheat bran and sugar beet pulp) was determined in Regional Center for Food and Feed

The control diets contained the requirements of all nutrients (Table 2), the calculated analysis for $1 \%$ of fiber sources recorded in Table 3 according to (RCFF, 2001), so the reduction in diets nurturance when diluted with different levels of WB were between 0.12 to $0.30 \%$ Crude

Table (2): Composition and calculated analysis of the experimental control diets.

\begin{tabular}{|c|c|c|c|}
\hline Ingredients & Starter & Grower & Finisher \\
\hline Yellow corn & 47.7 & 54.26 & 58.20 \\
\hline Soybean meal (46\% CP) & 24.83 & 21.10 & 8.49 \\
\hline Extrude full fat soya $(35 \% \mathrm{CP})$ & 19.36 & 16.98 & 22.08 \\
\hline Corn gluten feed $22 \%$ & - & - & 5.40 \\
\hline Corn gluten meal (60\%) & 2.00 & 2.00 & 2.01 \\
\hline Dried corn diet & 2.00 & - & - \\
\hline Soy oil refined & - & 1.69 & - \\
\hline Di-Ca Phosphate & 1.50 & 1.40 & 1.07 \\
\hline Limestone & 1.47 & 1.64 & 1.56 \\
\hline DL-methionine & 0.39 & 0.18 & 0.22 \\
\hline $\mathrm{NaCl}$ & 0.35 & 0.37 & 0.38 \\
\hline Vit. \& Min. Premix * & 0.30 & 0.30 & 0.30 \\
\hline Colin chloride $(60 \%)$ & 0.06 & 0.06 & 0.06 \\
\hline L lysinehydrochloride & 0.40 & 0.02 & 0.23 \\
\hline Total & 100 & 100 & 100 \\
\hline \multicolumn{4}{|l|}{ Calculated analysis $* *$} \\
\hline $\mathrm{CP} \%$ & 22.92 & 21.19 & 18.89 \\
\hline $\mathrm{ME} \mathrm{cal} / \mathrm{kg}$ & 3049.39 & 3169.96 & 3216.74 \\
\hline $\mathrm{CF} \%$ & 3.86 & 3.49 & 3.64 \\
\hline $\mathrm{EE} \%$ & 5.85 & 7.15 & 6.72 \\
\hline $\mathrm{Ca} \%$ & 0.912 & 0.95 & 0.85 \\
\hline Avi.P\% & 0.52 & 0.48 & 0.41 \\
\hline Lys.\% & 1.385 & 1.205 & 1.45 \\
\hline Meth\% & 0.80 & 0.56 & 0.55 \\
\hline Meth. +Cys.\% & 1.18 & 0.902 & 0.86 \\
\hline
\end{tabular}

* Premix contain per $3 \mathrm{~kg}$ vit $\mathrm{A} 12000000 \mathrm{IU}$, vit $\mathrm{D}_{3} 3300000 \mathrm{IU}$, vit E $30000 \mathrm{mg}$, vit $\mathrm{K}_{3} 3000 \mathrm{mg}$, vit B1 $2200 \mathrm{mg}$, vit B2 $8000 \mathrm{mg}$, vit B6 $4400 \mathrm{mg}$, vit B12 $22 \mathrm{mg}$, Niacin $66000 \mathrm{mg}$, Biotin $200 \mathrm{mg}$, Folic acid $1000 \mathrm{mg}$, pantothenic acid $12000 \mathrm{mg}$, Zinc $75000 \mathrm{mg}$, Manganese $134000 \mathrm{mg}$ Iron $100000 \mathrm{mg}$, Copper $8000 \mathrm{mg}$, Iodine 480mg, Cobalt $200 \mathrm{mg}$, Selenium $300 \mathrm{mg}$ and CaCO3 to $3000 \mathrm{~g}$ ** According the Egyptian Regional Center for Food and Feed (RCFF, 2001). 
Table (3): The calculated analysis for $1 \%$ of fiber sources

\begin{tabular}{lcc}
\hline Chemical analysis* & wheat bran & sugar beet pulp \\
\hline CP \% & 0.15 & 0.09 \\
ME cal/ kg & 14.00 & 6.46 \\
CF\% & 0.10 & 0.20 \\
EE\% & 0.04 & 0.001 \\
Ca \% & 0.001 & 0.007 \\
Avi.P\% & 0.003 & 0.0004 \\
Lys.\% & 0.006 & 0.006 \\
Meth\% & 0.002 & 0.0001 \\
Meth. +Cys.\% & 0.005 & 0.0002 \\
\hline
\end{tabular}

* According the Egyptian Regional Center for Food and Feed (RCFF, 2001).

protein, 35 to $87.3 \mathrm{kcal} / \mathrm{kg}$ metabolic energy, 0.05 to $0.13 \%$ ether extract, 0.02 to $0.04 \%$ calcium, 0.003 to $0.01 \%$ available phosphors, 0.02 to $0.04 \%$ lysine, 0.01 to $0.02 \%$ methionine and 0.01 to $0.02 \%$ methionine+ cysteine; and increased crude fiber by 0.13 to $0.32 \%$. Also, the reduction in diets nurturance when diluted with different levels of BP were between 0.24 to $0.60 \%$ Crude protein, 50 to $125 \mathrm{kcal} / \mathrm{kg}$ metabolic energy, 0.13 to $0.32 \%$ ether extract, 0.004 to $0.01 \%$ calcium, 0.007 to $0.023 \%$ Available phosphors, 0.01 to $0.04 \%$ lysine, 0.01 to $0.04 \%$ methionine and 0.02 to $0.04 \%$ methionine+ cysteine; and increased crude fiber by 0.33 to $0.82 \%$. The price of experimental diets recorded in Table (4). All chicks were fed on experimental diets ad libitum in wire battery cages and received the same management and veterinary procedures during the experimental period (1 - $42 \mathrm{~d})$. Growth performance parameters including live body weight (BW), body weight gain (BWG), feed intake (FI), and feed conversion ratio (FCR) were recorded during feeding phases and the overall experimental period. Rectal temperature and respiratory rate were recorded at the end of experimental.

Table (4): The price of experimental diets (LE/Ton of final feed).

\begin{tabular}{lccc}
\hline Treatment & Starter & Grower & Finisher \\
\hline Control & 7397 & 7022 & 6707 \\
WB2 & 7323 & 6955 & 6647 \\
WB3 & 7286 & 6922 & 6617 \\
WB4 & 7249 & 6889 & 6587 \\
WB5 & 7212 & 6856 & 6557 \\
BP2 & 7293 & 6925 & 6617 \\
BP3 & 7241 & 6877 & 6572 \\
BP4 & 7189 & 6829 & 6527 \\
BP5 & 7137 & 6781 & 6482 \\
\hline
\end{tabular}

\section{Carcass measurements:}

At 42 days of age, 4 birds of each treatment were randomly chosen to carry out slaughtering and sample processing procedures. Dressing, abdominal fat, and edible parts (liver, gizzard and heart) as percentages of BW were recorded. Front quarter (breast and wing) and back quarter (thigh and drumstick) cuts weight were recorded. All weights of carcass cuts were calculated as percentage from carcass weight. Intestine length, intestine weight, tibia length and tibia weight were recorded. Intestine index was calculated by the proportions of:

Intestine index $=$

$$
\text { intestine length }(\mathrm{cm})
$$

$$
\text { intestine weight }(\mathrm{g})
$$


Blood oxygen saturation \% $\left(\mathrm{O}_{2}\right)$ recorded during slaughtering. Blood samples were collected from birds during slaughter for blood oxygen determination of oxygen level using digital blood gas analyzer. Caecum $\mathrm{pH}$ was recorded by digital $\mathrm{pH}$ - meter. The economical and the relative economical efficiency (REE) were calculated in relation to local market prices at time of the experiment.

\section{Statistical analysis:}

Data of two sources of DD, wheat bran (WB) and sugar beet pulp (BP) with 4 levels were subjected to two-way analysis of variance to detect the effects of both sources and levels of DD. Also data of the 9 treatments including control were subjected to one-way analysis of variance to detect the differences between them.

Variables showing a significant F-test $(\mathrm{p}<0.05)$ were compared to each other's using Duncan's Multiple Range Test (Duncan, 1955). The statistical procedures were computed using SAS (2001). The models of statistical analysis were:

Two-way analysis:

Where:

$$
\mathbf{Y}_{\mathrm{ijk}}=\mu+\mathbf{D}_{\mathrm{i}}+\mathrm{L}_{\mathrm{j}}+(\mathrm{DL})_{\mathrm{ij}}+\mathbf{e}_{\mathrm{ijk}}
$$

$\mathrm{Y}_{\mathrm{ijk}}=$ Trait measured.

$\mu=$ Overall mean.

$\mathrm{D}_{\mathrm{i}}=$ Dilution sources, Wheat bran(BP) or sugar beet pulp dilution (WB).

$\mathrm{L}_{\mathrm{j}}=$ Levels of diet dilution.

$\mathrm{DL}_{\mathrm{ij}}=$ Interaction between sources and levels of diet dilution.

$\mathrm{e}_{\mathrm{ijk}}=$ Experimental error.

One-way analysis:

Where:

$$
\mathbf{Y}_{\mathrm{ij}}=\boldsymbol{\mu}+\mathbf{T}_{\mathrm{i}}+\mathbf{e}_{\mathrm{ij}}
$$

$\mathrm{Y}_{\mathrm{ij}}=$ Trait measured.

$\mu=$ Overall mean of Yij.

$\mathrm{T}_{\mathrm{i}}=$ Effect of treatment, $\mathrm{i}=(1, \ldots, 9)$.

$\mathrm{e}_{\mathrm{ij}}=$ Experimental error.

\section{RESULTS AND DISCUTION}

\section{Analysis of fiber fraction:}

Analysis of fiber fraction for dilution sources (wheat bran and sugar beet pulp) are listed in Table (5).

Table (5): Fiber fraction analyzes for diets and fiber sources.

\begin{tabular}{lcc}
\hline Fiber fraction & Wheat bran & Sugar beet pulp \\
\hline Hemicelluloses & 19.90 & 8.36 \\
Cellulose & 5.98 & 18.02 \\
Lignin & 3.14 & 3.90 \\
Neutral Detergent fiber (NDF) & 29.38 & 31.27 \\
Acid Detergent fiber (ADF) & 9.47 & 22.90 \\
Acid Detergent lignin (ADL) & 3.50 & 4.88 \\
\hline
\end{tabular}

\section{Growth performance:}

Results in Tables (6 and 7) show the effect of dilution with WB and BP at different levels and their interactions on performance of broilers chicks. Dilution diet with WB significantly recorded higher BW and BWG at end of starter, finisher and overall periods compared BP by 4.3 and $1.1 \%$ for starter and finisher BW, and 5.7, 1.5 and $1.1 \%$ for starter, finisher and final BWG, respectively. Also, broiler FCR significantly improved during all phases by dilution with WB except grower phase whereas BP showed better FCR. Stater, finisher and overall period FCR improved by 4.2, 2.5 and $1.3 \%$, respectively for WB dilution and grower FCR improved by $3.3 \%$ for BP dilution. 
Table (6): Effect of DD using wheat bran or sugar beet pulp at deferent levels on the performance of broilers chicks during starter and grower periods.

\begin{tabular}{lccccccc}
\hline Treatment & \multicolumn{3}{c}{ Finisher(25- 42 d of age) } & \multicolumn{3}{c}{ Overall period ( at 42 d of age) } \\
\cline { 2 - 8 } & BW (g) & BWG(g) & FI (g) & FCR & BWG (g) & FI (g) & FCR \\
\hline Main effect & & & DD Sources & & & \\
Wheat bran & $2192.9^{\mathrm{a}}$ & $1471.9^{\mathrm{a}}$ & $2255.1^{\mathrm{b}}$ & $1.54^{\mathrm{b}}$ & $2152.9^{\mathrm{a}}$ & 3266.1 & $1.52^{\mathrm{b}}$ \\
Sugar Bet & $2168.7^{\mathrm{b}}$ & $1449.7^{\mathrm{b}}$ & $2285.0^{\mathrm{a}}$ & $1.58^{\mathrm{a}}$ & $2128.6^{\mathrm{b}}$ & 3271.5 & $1.54^{\mathrm{a}}$ \\
pulp & & & & & & & \\
Mean of SE & \pm 5.56 & \pm 6.10 & \pm 8.53 & \pm 0.004 & \pm 6.04 & \pm 9.42 & \pm 0.004 \\
Probability & $* *$ & $*$ & $*$ & $* *$ & $* *$ & NS & $* *$ \\
& & & & DD Levels & & & \\
$2 \%$ & $2177.4^{\mathrm{b}}$ & $1447.9^{\mathrm{b}}$ & $2307.1^{\mathrm{a}}$ & $1.59^{\mathrm{a}}$ & $2137.0^{\mathrm{b}}$ & $3326.3^{\mathrm{a}}$ & $1.56^{\mathrm{a}}$ \\
$3 \%$ & $2161.7^{\mathrm{b}}$ & $1410.1^{\mathrm{c}}$ & $2223.7^{\mathrm{b}}$ & $1.58^{\mathrm{a}}$ & $2121.7^{\mathrm{b}}$ & $3239.3^{\mathrm{c}}$ & $1.53^{\mathrm{b}}$ \\
$4 \%$ & $2206.3^{\mathrm{a}}$ & $1494.7^{\mathrm{a}}$ & $2297.3^{\mathrm{a}}$ & $1.54^{\mathrm{b}}$ & $2166.4^{\mathrm{a}}$ & $3279.7^{\mathrm{b}}$ & $1.52^{\mathrm{b}}$ \\
$5 \%$ & $2177.8^{\mathrm{b}}$ & $1490.4^{\mathrm{a}}$ & $2252.0^{\mathrm{b}}$ & $1.52^{\mathrm{c}}$ & $2138.1^{\mathrm{b}}$ & $3230.0^{\mathrm{c}}$ & $1.52^{\mathrm{b}}$ \\
Mean of SE & \pm 7.87 & \pm 8.62 & \pm 12.06 & \pm 0.01 & \pm 8.54 & \pm 13.32 & \pm 0.01 \\
Probability & $* *$ & $* *$ & $* *$ & $* *$ & $* *$ & $* *$ & $* *$ \\
& & & & Treatments & & & \\
\hline
\end{tabular}

${ }^{a-e}=$ Means in the same raw with different superscripts, differ significantly. $D D=$ diet dilution

$B W=$ Body weight. $B W G=$ Body weight gain. FI= Feed intake. $F C R=$ feed conversion ratio.

$W B=$ wheat bran $\quad B P=$ sugar beet pulp NS: Non-significant $\quad *: P \leq 0.05 . * *: P \leq 0.01 . \quad$ SE: Standard errors.

Table (7): Effect of DD using wheat bran or sugar beet pulp at deferent levels on the performance of broilers chicks during finisher and overall experimental periods

\begin{tabular}{|c|c|c|c|c|c|c|c|c|}
\hline \multirow[b]{2}{*}{ Treatment } & \multicolumn{3}{|c|}{ Carcass } & \multicolumn{2}{|c|}{ Front quarter (FQ) } & \multicolumn{3}{|c|}{ Back quarter (BQ) } \\
\hline & Dressing & Edible Parts & Abdominal fat & Breast & Wing & $\begin{array}{c}\text { Total } \\
\text { Weight }\end{array}$ & Thigh Weight & $\begin{array}{c}\text { Drums Stick } \\
\text { (DS) }\end{array}$ \\
\hline \multicolumn{9}{|l|}{ Main effect } \\
\hline & \multicolumn{8}{|c|}{ DD Source } \\
\hline Wheat bran & $73.16^{b}$ & 4.22 & 0.82 & $20.13^{b}$ & $3.14^{b}$ & $14.50^{b}$ & 9.55 & $4.95^{b}$ \\
\hline Sugar Beet pulp & $74.81^{a}$ & 4.17 & 0.79 & $21.84^{a}$ & $3.54^{a}$ & $15 \cdot 50^{a}$ & 9.76 & $5.74^{a}$ \\
\hline Mean of SE & \pm 0.26 & \pm 4.22 & \pm 0.82 & \pm 20.13 & \pm 3.14 & \pm 14.50 & \pm 9.55 & \pm 4.95 \\
\hline Probability & $* *$ & NS & NS & $* *$ & $* *$ & $* *$ & NS & $*$ \\
\hline & \multicolumn{8}{|c|}{ DD Levels } \\
\hline $2 \%$ & $73.16^{b}$ & 3.96 & $1.06^{a}$ & $21.51^{a}$ & $3.35^{a b}$ & $14.61^{\mathrm{bc}}$ & $9.46^{\mathrm{b}}$ & 5.15 \\
\hline $3 \%$ & $70.78^{c}$ & 4.19 & $0.67^{b}$ & $19.34^{b}$ & $3.20^{b}$ & $14.39^{c}$ & $8.82^{c}$ & 5.57 \\
\hline $4 \%$ & $76.35^{a}$ & 4.15 & $0.99^{a}$ & $21.40^{a}$ & $3.32^{a b}$ & $15.32^{\mathrm{ab}}$ & $10.00^{a b}$ & 5.32 \\
\hline $5 \%$ & $75.64^{a}$ & 4.47 & $0.49^{c}$ & $21.71^{a}$ & $3.50^{\mathrm{a}}$ & $15.68^{a}$ & $10.32^{a}$ & 5.35 \\
\hline Mean of SE & \pm 0.37 & \pm 0.21 & \pm 0.05 & \pm 0.35 & \pm 0.09 & \pm 0.28 & \pm 0.21 & \pm 0.33 \\
\hline \multirow[t]{2}{*}{ Probability } & $* *$ & NS & $* *$ & $* *$ & $*$ & $*$ & $* *$ & NS \\
\hline & \multicolumn{8}{|c|}{ Treatments } \\
\hline Control & $71.22^{c}$ & 3.87 & $1.37^{\mathrm{a}}$ & $20.30^{c}$ & $3.03^{d}$ & $14.15^{c d}$ & $9.51^{\mathrm{bcd}}$ & $4.65^{b}$ \\
\hline WB2\% & $72.02^{c}$ & 3.94 & $1.24^{a}$ & $20.54^{\mathrm{bc}}$ & $3.13^{\mathrm{bcd}}$ & $13.69^{d}$ & $8.70^{d}$ & $4.98^{a b}$ \\
\hline WB3\% & $69.29^{d}$ & 4.09 & $0.62^{\text {de }}$ & $17.25^{\mathrm{d}}$ & $2.85^{a}$ & $13 \cdot 58^{d}$ & $8.70^{d}$ & $4.89^{a b}$ \\
\hline WB4\% & $74.72^{b}$ & 3.98 & $1.00^{\mathrm{b}}$ & $20.57^{\mathrm{bc}}$ & $3.07^{c d}$ & $14.64^{\mathrm{bcd}}$ & $9.93^{a b c}$ & $4.72^{\mathrm{b}}$ \\
\hline WB5\% & $76.60^{\mathrm{a}}$ & 4.87 & $0.43^{e}$ & $22.18^{\mathrm{ab}}$ & $3.51^{a b}$ & $16.09^{\mathrm{a}}$ & $10.87^{a}$ & $5.21^{\mathrm{ab}}$ \\
\hline $\mathrm{BP} 2 \%$ & $74.29^{b}$ & 3.98 & $0.88^{\mathrm{bc}}$ & $22.49^{a}$ & $3.58^{a}$ & $15 \cdot 54^{\mathrm{ab}}$ & $10.23^{a b}$ & $5 \cdot 31^{a b}$ \\
\hline BP3\% & $72.27^{b}$ & 4.29 & $0.73^{c d}$ & $21.43^{a b c}$ & $3.55^{a b}$ & $15.19^{a b c}$ & $8.95^{c d}$ & $6.24^{\mathrm{a}}$ \\
\hline $\mathrm{BP} 4 \%$ & $77.99^{a}$ & 4.31 & $0.98^{\mathrm{b}}$ & $22.23^{\mathrm{ab}}$ & $3.56^{\mathrm{ab}}$ & $16.01^{\mathrm{a}}$ & $10.08^{\mathrm{ab}}$ & $5.93^{\mathrm{ab}}$ \\
\hline BP5\% & $74.68^{b}$ & 4.08 & $0.56^{\text {de }}$ & $21.23^{a b c}$ & $3.48^{a b c}$ & $15.27^{\mathrm{abc}}$ & $9.78^{\mathrm{abcd}}$ & $5.49^{a b}$ \\
\hline Mean of SE & \pm 0.54 & \pm 0.30 & \pm 0.07 & \pm 0.52 & \pm 0.14 & \pm 0.41 & \pm 0.34 & \pm 0.44 \\
\hline Probability & $* *$ & NS & $* *$ & $* *$ & $* *$ & $* *$ & $* *$ & $*$ \\
\hline
\end{tabular}

$\cdot^{a-e}=$ Means in the same raw with different superscripts, differ significantly.DD $=$ diet dilution. BW $=$ Body weight. $B W G=$ Body weight gain. $F I=$ Feed intake. $F C R=$ feed conversion ratio. $W B=$ wheat bran $B P=$ sugar beet pulp *: $P \leq 0.05$. **: $P \leq 0.01$. SE: Standard errors.

The levels of dilution 2, 3, 4 and $5 \%$ affected significantly on broiler BW and BWG during all phases of production. The levels 2, 3 and $4 \%$ of DD improved starter and grower broilers BW and BWG 
compared the level of $5 \%$. But during finisher phase broilers fed DD at $4 \%$, significant recorded the highest BW and BWG. Also broiler fed DD at $4 \%$ recorded significantly the highest overall BWG. The levels of dilution had no significant effect during starter and grower phases on FI, while broilers fed diet diluted with 2 and $4 \%$ significant increased FI compared with other levels during finisher phase. The highest overall FI significantly recorded by broiler fed diet diluted by $2 \%$ followed by $4 \%$ while applying levels of 3 and $5 \%$ DD showed the lowest consumed feed values, respectively.

Among DD levels, during starter phase level 5\% DD showed the worst FCR, however, during grower phase, the best value of FCR was recorded by group of 3\% of DD. The best FCR during finisher phase recorded by broiler fed DD at $5 \%$ followed by $4 \%$ compared with other levels. Regarding to overall period, levels of DD at 3,4 and $5 \%$ recorded the best significant FCR compared with level $2 \%$.

Among all treatments (included control group), broiler fed control, WB3, WB4, BP2 and WB2, respectively showed the highest $\mathrm{BW}$ and BWG during starter phase follow by other treatments. The broiler fed BP3 and BP5 significantly recorded the lowest BW and BWG compared control and BW3. On the contrary, during grower period BP3 significant recorded the highest BW and BWG followed by BP2 compared control and BP5. During the grower and final phaseWB5 showed the highest BW and BWG compared with all other treatments, followed by WB4 and BP2. The lowest value for BW and BWG recorded by BP5.

The results showed that the worst FCR during starter phase significant recorded by BW5, BP3 and BP5 1.47, 1.48 and 1.48, respectively compared with control. The best FCR significant recorded by WB3 and WB4 1.32 and 1.34, respectively compared with WB5, BP3 and BP5.During grower phase BP3 surpassed and improved FCR (1.41) compared with all treatments and significant compared with control, WB2, WB4 and BP5 (1.54, 1.54, 154 and 1.53, respectively). The FCR for broiler fed WB5 significant recorded the best value compared with all treatments during finisher and final phase followed by BW4, BP3, BP2 and BP4 compared control, WB2 and BP5.

These results are in agreement with those reported by Sahraei and Shariatmadari (2007) who showed improving of body weight in different levels of DD at levels 7, 14 or $21 \%$ using WB (wt:wt) compared with control group while level28\% increase feed intake. Also, Shang et al., (2020) reported replacing $30 \mathrm{~g}$ WB/kg (3\%) diet enhanced nutrient digestibility by improving antioxidant status, gizzard development, intestinal digestive enzyme activities and morphology in broilers. They concluded that wheat bran could be used for improving feed efficiency in broilers. AbouSekken et al., (2013) reported that sugar beet pulp as a source of digestive fibers could be used in broiler diets up to $3 \%$ without negative effects on performance and the effect of BP levels in starter period showed that beet pulp level at $1 \%$ was significant on broiler performance. This result agrees with Mateos et al., (2002) who reported that the inclusion of fiber in the diet might benefit nutrient digestibility and growth performance in broilers. Moreover, Gonzalez Alvarado et al., (2007 and 2010) reported that young broiler chicks require minimal amount of fiber in the diet. Data obtained during grower period indicated that BP level at 3\% was the best compared with 3\% oat hulls and control. These results supported the findings of Jimenez-Moreno et al., (2009 a and b) showed that using dietary $3 \% \mathrm{BP}$ recorded the best growth performance compared to the control during period from 1-25 days. Also, the same results were observed during finisher and total periods. These results agree with Koschayev et al., (2019) who found that replacing chickens diets by $4 \%$ of dry BP during 21-41 days has a positive impact on their productivity.

\section{Carcass quality and morphometric parameters:}

Effects of DD of using WB and BP with different levels and their interactions on broiler carcass quality at 42 days are presented in Table (8). Results recorded significant differences between broilers fed DD with WB compared with BP, the dressing, breast, wing, total weight of BQ and DS \% were significantly higher for those fed $\mathrm{PB}$. Increasing levels of DD reflected on increasing dressing percent, the broiler fed 4 and $5 \%$ recorded the higher percent 76.35 and $75.64 \%$, respectively compared with 2 and 3 $\%$ (73.16 and $70.78 \%$, respectively).

Appling the higher level of dilution 5\% decreased the abdominal fat percent by $53.77 \%$ compared with level $2 \%$. However, DD at 2 and $4 \%$ showed the higher values of abdominal fat $\%$. Among levels of $\mathrm{DD}$, general reduction of breast meat, wings, BQ and thigh\% was observed for level 3\% compared with other levels, while levels 4 and 5\% showed the highest value of such cuts.

Results of treatments showed significant differences on all carcass traits except edible parts. The broiler fed BP4 and WB5 recorded the highest dressing \% compared with all treatments 77.99 and 76.60 $\%$, respectively. While, the lowest value of dressing \% recorded by broilers fed WB3 (69.29\%) compared with all treatments. All treatments significantly decreased abdominal fat\% compared to control except WB2. The lowest values recorded by WB3, WB5 and BP5 by 45.74, 68.61 and $59.12 \%$, respectively. 
While results of breast meat, wings and BQ showed different trend, whereas samples of WB5, BP2 and BP4 recorded significantly highest values compared with other treatments. However, the highest value of DS recorded by broiler fed BP3 compared to control and WB4.

These results agree with Koschayev et al., (2019) recorded that replacing chickens diets by $4 \%$ of dry $\mathrm{BP}$ has a positive impact on the quality of meat products. AbouSekken et al., (2013) reported that BP as a source of fibers could be used in broiler diets up to $3 \%$ without negative effects on carcass characteristics. No significant differences between broiler groups fed experimental dietary BP levels, except the relative weight of gizzard and heart which was significantly increased with release of BP level.

Data of intestine length, intestine index $(\mathrm{cm} / \mathrm{g})$, caecum $\mathrm{pH}$, tibia length and weight $\%$ as affected by DD using WB and BP at different levels and their interactions at 42 day of age are presented in Table (9). The obtained results indicated no significant effects due to experimental factors on the examined mentioned parameters, however, tibia weight \% increased by WB compared to BP (1.27 vs.1.09 \%). Among DD levels, $4 \%$ showed the lowest value of tibia weight $(0.98 \%)$, while 3 and $4 \%$ recorded the highest values (1.31 and $1.32 \%$ ) compared with levels 5 and $2 \%$, respectively.

Concerning interaction between DD sources and levels, results cleared significant effect on intestine length, intestine index and tibia weight \%. The intestine length recorded higher values for WB4, BP2, WB5 compared to others. Broiler fed WB3 and WB4 were showed significantly the highest intestine index compared to WB2. Treatments WB4, WB5 and BP2 showed increased values of both intestine length and intestine index. In addition, WB5 recorded the highest value of tibia weight (1.67\%) compared with most of treatments including control group. While groups of WB4, BP4 and BP5 recorded the lowest value $(0.98 \%)$. The obtained results of caecum $\mathrm{pH}$ for main factors and treatments showed nonsignificant effect. While BP4 showed the higher numerical value (6.4) followed by BP4(6.03) and control (6.08). The rest of treatments ranged between 5.33 to 5.75. Values recorded by WB4 and WB5 showed the lowest numerical values of caecum $\mathrm{pH}$ (5.33 and 5.4, respectively).

Table (8): Effect of wheat bran and sugar beet pulp with deferent levels on some carcass parameters of broiler chicks at 42 days of age.

\begin{tabular}{|c|c|c|c|c|c|c|c|c|}
\hline \multirow[b]{2}{*}{ Treatment } & \multicolumn{3}{|c|}{ Carcass } & \multicolumn{2}{|c|}{ Front quarter (FQ) } & \multicolumn{3}{|c|}{ Back quarter (BQ) } \\
\hline & Dressing & $\begin{array}{l}\text { Edible } \\
\text { Parts }\end{array}$ & $\begin{array}{l}\text { Abdominal } \\
\text { fat }\end{array}$ & Breast & Wing & $\begin{array}{c}\text { Total } \\
\text { Weight }\end{array}$ & $\begin{array}{l}\text { Thigh } \\
\text { Weight }\end{array}$ & $\begin{array}{c}\text { Drums } \\
\text { Stick (DS) }\end{array}$ \\
\hline Main effect & \multicolumn{8}{|c|}{ DD Sources } \\
\hline Wheat bran & $73.16^{\mathrm{b}}$ & 4.22 & 0.82 & $20.13^{\mathrm{b}}$ & $3.14^{\mathrm{b}}$ & $14.50^{\mathrm{b}}$ & 9.55 & $4.95^{\mathrm{b}}$ \\
\hline $\begin{array}{l}\text { Sugar } \quad \text { Beet } \\
\text { pulp }\end{array}$ & $74.81^{\mathrm{a}}$ & 4.17 & 0.79 & $21.84^{\mathrm{a}}$ & $3.54^{\mathrm{a}}$ & $15.50^{\mathrm{a}}$ & 9.76 & $5.74^{\mathrm{a}}$ \\
\hline Mean of SE & \pm 0.26 & \pm 4.22 & \pm 0.82 & \pm 20.13 & \pm 3.14 & \pm 14.50 & \pm 9.55 & \pm 4.95 \\
\hline \multirow[t]{2}{*}{ Probability } & $* *$ & NS & NS & $* *$ & $* *$ & $* *$ & NS & $*$ \\
\hline & \multicolumn{8}{|c|}{ DD Levels } \\
\hline $2 \%$ & $73.16^{\mathrm{b}}$ & 3.96 & $1.06^{\mathrm{a}}$ & $21.51^{\mathrm{a}}$ & $3.35^{\mathrm{ab}}$ & $14.61^{\mathrm{bc}}$ & $9.46^{\mathrm{b}}$ & 5.15 \\
\hline $3 \%$ & $70.78^{\mathrm{c}}$ & 4.19 & $0.67^{\mathrm{b}}$ & $19.34^{\mathrm{b}}$ & $3.20^{\mathrm{b}}$ & $14.39^{c}$ & $8.82^{\mathrm{c}}$ & 5.57 \\
\hline $4 \%$ & $76.35^{\mathrm{a}}$ & 4.15 & $0.99^{\mathrm{a}}$ & $21.40^{\mathrm{a}}$ & $3.32^{\mathrm{ab}}$ & $15.32^{\mathrm{ab}}$ & $10.00^{\mathrm{ab}}$ & 5.32 \\
\hline $5 \%$ & $75.64^{\mathrm{a}}$ & 4.47 & $0.49^{\mathrm{c}}$ & $21.71^{\mathrm{a}}$ & $3.50^{\mathrm{a}}$ & $15.68^{\mathrm{a}}$ & $10.32^{\mathrm{a}}$ & 5.35 \\
\hline Mean of SE & \pm 0.37 & \pm 0.21 & \pm 0.05 & \pm 0.35 & \pm 0.09 & \pm 0.28 & \pm 0.21 & \pm 0.33 \\
\hline \multirow[t]{2}{*}{ Probability } & $* *$ & NS & $* *$ & $* *$ & $*$ & $*$ & $* *$ & NS \\
\hline & \multicolumn{8}{|c|}{ Treatments } \\
\hline Control & $71.22^{\mathrm{c}}$ & 3.87 & $1.37^{\mathrm{a}}$ & $20.30^{c}$ & $3.03^{\mathrm{d}}$ & $14.15^{\mathrm{cd}}$ & $9.51^{\mathrm{bcd}}$ & $4.65^{\mathrm{b}}$ \\
\hline WB2\% & $72.02^{c}$ & 3.94 & $1.24^{\mathrm{a}}$ & $20.54^{b c}$ & $3.13^{\mathrm{bcd}}$ & $13.69^{\mathrm{d}}$ & $8.70^{\mathrm{d}}$ & $4.98^{\mathrm{ab}}$ \\
\hline WB3\% & $69.29^{\mathrm{d}}$ & 4.09 & $0.62^{\mathrm{de}}$ & $17.25^{\mathrm{d}}$ & $2.85^{\mathrm{d}}$ & $13.58^{\mathrm{d}}$ & $8.70^{\mathrm{d}}$ & $4.89^{\mathrm{ab}}$ \\
\hline WB4\% & $74.72^{\mathrm{b}}$ & 3.98 & $1.00^{\mathrm{b}}$ & $20.57^{\text {bc }}$ & $3.07^{\mathrm{cd}}$ & $14.64^{\mathrm{bcd}}$ & $9.93^{\mathrm{abc}}$ & $4.72^{\mathrm{b}}$ \\
\hline WB5\% & $76.60^{\mathrm{a}}$ & 4.87 & $0.43^{\mathrm{e}}$ & $22.18^{\mathrm{ab}}$ & $3.51^{\mathrm{ab}}$ & $16.09^{\mathrm{a}}$ & $10.87^{\mathrm{a}}$ & $5.21^{\mathrm{ab}}$ \\
\hline $\mathrm{BP} 2 \%$ & $74.29^{\mathrm{b}}$ & 3.98 & $0.88^{\mathrm{bc}}$ & $22.49^{\mathrm{a}}$ & $3.58^{\mathrm{a}}$ & $15.54^{\mathrm{ab}}$ & $10.23^{\mathrm{ab}}$ & $5.31^{\mathrm{ab}}$ \\
\hline BP3\% & $72.27^{\mathrm{b}}$ & 4.29 & $0.73^{\mathrm{cd}}$ & $21.43^{\mathrm{abc}}$ & $3.55^{\mathrm{ab}}$ & $15.19^{\mathrm{abc}}$ & $8.95^{\mathrm{cd}}$ & $6.24^{\mathrm{a}}$ \\
\hline $\mathrm{BP} 4 \%$ & $77.99^{\mathrm{a}}$ & 4.31 & $0.98^{\mathrm{b}}$ & $22.23^{\mathrm{ab}}$ & $3.56^{\mathrm{ab}}$ & $16.01^{\mathrm{a}}$ & $10.08^{\mathrm{ab}}$ & $5.93^{\mathrm{ab}}$ \\
\hline BP5\% & $74.68^{\mathrm{b}}$ & 4.08 & $0.56^{\mathrm{de}}$ & $21.23^{\mathrm{abc}}$ & $3.48^{\mathrm{abc}}$ & $15.27^{\mathrm{abc}}$ & $9.78^{\mathrm{abcd}}$ & $5.49^{\mathrm{ab}}$ \\
\hline Mean of SE & \pm 0.54 & \pm 0.30 & \pm 0.07 & \pm 0.52 & \pm 0.14 & \pm 0.41 & \pm 0.34 & \pm 0.44 \\
\hline Probability & $* *$ & NS & $* *$ & $* *$ & $* *$ & $* *$ & $* *$ & $*$ \\
\hline
\end{tabular}


Generally, the results showed healthy impact of applying DD to broiler diets on intestine and bone characterization. Birds of WB4 and WB5 showed healthy indicators of intestine as intestine length and intestine index had increased combined with numerical reduction in caecum $\mathrm{pH}$. These results confirmed the previous reports by Shang et al., (2020) and Vermeulen et al.(2017). Shang et al., (2020) reported WB supplementation $(30 \mathrm{~g} / \mathrm{kg})$ in broilers diet the relative length of small intestine did not significantly vary with any of the dietary treatments. Also, Vermeulen et al. (2017) observed that fine wheat bran addition can improve colonization by lactate and butyrate producing microbiota. Subsequently fermentation by the microbiota in the chicken's gastrointestinal tract (GIT) can then even lead to a beneficial impact. The different segments of the chicken's GIT are characterized and colonized by a diverse and complex set of microorganisms, which strongly impact nutrient uptake and utilization, GIT development, physiology and immunity, and invasion of GIT pathogens (Apajalahti et al., 2007; Pan and Yu, 2014 and Rehman et al., 2007). The better tibia length and weight recorded by WB5 may be due to the high content of WB from available phosphorus $(0.6 \%)$ which support bone quality.

Table (9): Effect of wheat bran and sugar beet pulp with deferent levels on some Intestine and bone measurements of broiler chicks at 42 days of age.

\begin{tabular}{|c|c|c|c|c|c|}
\hline \multirow{2}{*}{ Treatment } & \multicolumn{2}{|c|}{ Intestine } & \multirow{2}{*}{ Caecum pH } & \multicolumn{2}{|c|}{ Tibia } \\
\hline & Length $(\mathrm{cm})$ & Index & & Length $(\mathrm{cm})$ & Weight $\%$ \\
\hline \multicolumn{6}{|l|}{ Main effect } \\
\hline Wheat bran & 198.92 & 1.46 & $\begin{array}{l}\text { DD Sourc } \\
5.54\end{array}$ & 10.37 & $1.27^{\mathrm{a}}$ \\
\hline Sugar Beet pulp & 198.00 & 1.41 & 5.93 & 10.12 & $1.09^{\mathrm{b}}$ \\
\hline Mean of SE & \pm 198.92 & \pm 1.41 & \pm 0.23 & \pm 10.37 & \pm 1.27 \\
\hline Probability & NS & NS & $\begin{array}{l}\text { NS } \\
\text { DD Level }\end{array}$ & NS & $*$ \\
\hline $2 \%$ & 198.17 & 1.37 & 6.07 & 10.50 & $1.11^{\mathrm{ab}}$ \\
\hline $3 \%$ & 195.83 & 1.44 & 5.62 & 10.33 & $1.31^{\mathrm{a}}$ \\
\hline $4 \%$ & 198.67 & 1.53 & 5.68 & 10.00 & $0.98^{\mathrm{b}}$ \\
\hline $5 \%$ & 201.17 & 1.40 & 5.57 & 10.17 & $1.32^{\mathrm{a}}$ \\
\hline Mean of SE & \pm 3.51 & \pm 0.05 & \pm 0.33 & \pm 0.41 & \pm 0.08 \\
\hline Probability & NS & NS & $\begin{array}{l}\text { NS } \\
\text { Treatmen }\end{array}$ & NS & $*$ \\
\hline Control & $191.33^{\text {bcd }}$ & $1.52^{\mathrm{ab}}$ & 6.08 & 10.07 & $1.08^{\mathrm{b}}$ \\
\hline WB2\% & $180.66^{\mathrm{d}}$ & $1.27^{\mathrm{b}}$ & 5.75 & 11.33 & $1.11^{\mathrm{b}}$ \\
\hline WB3\% & $197.66^{\mathrm{bc}}$ & $1.54^{\mathrm{a}}$ & 5.68 & 9.83 & $1.33^{\mathrm{ab}}$ \\
\hline WB4\% & $213.66^{\mathrm{a}}$ & $1.55^{\mathrm{a}}$ & 5.33 & 10.00 & $0.98^{\mathrm{b}}$ \\
\hline WB5\% & $203.66^{\mathrm{ab}}$ & $1.46^{\mathrm{ab}}$ & 5.40 & 10.33 & $1.67^{\mathrm{a}}$ \\
\hline BP2\% & $215.66^{\mathrm{a}}$ & $1.47^{\mathrm{ab}}$ & 6.40 & 9.67 & $1.11^{\mathrm{b}}$ \\
\hline ВР3\% & $194.00^{\text {bcd }}$ & $1.34^{\mathrm{ab}}$ & 5.57 & 10.83 & $1.29^{\mathrm{ab}}$ \\
\hline BP4\% & $183.66^{\mathrm{cd}}$ & $1.50^{\mathrm{ab}}$ & 6.03 & 10.00 & $0.98^{\mathrm{b}}$ \\
\hline BP5\% & $198.66^{\mathrm{bc}}$ & $1.34^{\mathrm{ab}}$ & 5.73 & 10.00 & $0.98^{\mathrm{b}}$ \\
\hline Mean of SE & \pm 4.73 & \pm 0.07 & \pm 0.44 & \pm 0.54 & \pm 0.12 \\
\hline Probability & $* *$ & * & NS & NS & $*$ \\
\hline
\end{tabular}

${ }^{a-d}=$ Means in the same colum with different superscripts, differ significantly. WB $=$ wheat bran $B P=$ sugar beet pulp NS: Non-significant $D D=$ diet dilution. *: $P \leq 0.05 . * *: P \leq 0.01 . \quad$ SE: Standard errors.

Regarding to BP, BP3 showed combined indicators of intestine health and bone quality. This support results by AbouSekken et al., (2013) showed that length and total counts of microflora in ceca significantly increased with the highest level of BP up to 5\%. Diao et al., (2020) feeding a high-fiber diet (5.74\% CF, obtained from BP as $25 \%$ from diets) to pigs exerted beneficial effects by improving the intestinal health of growing pigs. The beet pulp group had a higher weight of the whole intestine and small intestine, higher density of the whole intestine and large intestine, and longer length of the large intestine than the control group. Bautil et al., (2019) cocluded that, depending on the dietary ingredients and the age of broilers, microbiota will contribute differently to fiber degradation and fermentation. Hence, nutritional intervention strategies need to take into account and encourage the age-related and diet-adapted fiber degrading potential of the intestinal microbiota. Stimulating the microbial hydrolysis and fermentation capacity of dietary arabinoxylan substrates at young broiler ages. Older broilers compared to younger chicks will better perform on NSP-rich diets, due to a decrease in their susceptibility 
towards the anti-nutritional factors of dietary NSP. Furthermore, the establishment of a mature intestinal microbiome and a fully developed GIT at later ages further enhances the digestibility of NSP-rich diets towards slaughter age (Batal and Parsons, 2002; Noy and Sklan, 2002; Masey O'Neill et al., 2012 and Lee et al., 2017).

It could be concluded that using low density feed ingredients during starting and growing periods could enhance the final marketed weight throw its effect on intestine health and GIT capacity. Using DD material which contains good levels of minerals (like WB), has better opportunity to support mineralization of bones during early stages and this help to enhance muscles growth during finisher phase.

\section{Stress indicators:}

The effect of DD of using WB and BP at different levels and their interactions on respiration rates (RR), rectal temperature(RT) and blood oxygen saturation $\%\left(\mathrm{O}_{2}\right)$ presented in Table (10). The results showed that no significant effects of DD source on the examined parameters except RR, the DD using BP significantly higher than WB (63.3 vs 59.5). Whoever, their levels had a significant effect on RT and $\mathrm{O}_{2}$ $\%$. The broiler which subjected to $4 \%$ DD recorded significantly the lowest value of RT $\left(40.63^{\circ} \mathrm{C}\right)$ compared with other levels $\left(41.33^{\circ} \mathrm{C}\right)$. Also, the broiler which subjected to $5 \%$ and $2 \%$ DD showed increased level of blood oxygen saturation \% (78.44 and 75.39, respectively).

Among experimental treatments, all treatments decreased RT significantly compared to control. Both BP4 and WB4 recorded the lowest RT 40.6 and $40.7^{\circ} \mathrm{C}$, respectively compared to other treatments. Also, WB3, WB4 and WB5 decreased RR significantly compared with control. The lowest value recorded by WB5 (57.0) compared to other treatment, followed by WB4

Table (10): Effect of wheat bran and sugar beet pulp with deferent levels on Respiration rates, rectal temperature and blood oxygen of broilers chicks.

\begin{tabular}{|c|c|c|c|}
\hline Treatment & $\mathrm{RT}\left({ }^{\circ} \mathrm{C}\right)$ & $\begin{array}{c}\text { RR } \\
\text { (No. times of breath/ bird/min) }\end{array}$ & $\mathrm{O}_{2}(\%)$ \\
\hline Main effect & Fibers & & \\
\hline Wheat bran & 41.2 & $59.5^{\mathrm{b}}$ & 73.8 \\
\hline Sugar Beet pulp & 41.1 & $63.3^{\mathrm{a}}$ & 75.5 \\
\hline Mean of SE & \pm 0.1 & \pm 0.8 & \pm 1.1 \\
\hline Probability & NS & $*$ & NS \\
\hline \multicolumn{4}{|c|}{ Levels } \\
\hline $2 \%$ & $41.3^{\mathrm{a}}$ & 63.6 & $75.4^{\mathrm{a}}$ \\
\hline $3 \%$ & $41.3^{\mathrm{a}}$ & 61.1 & $70.2^{\mathrm{b}}$ \\
\hline $4 \%$ & $40.6^{\mathrm{b}}$ & 60.5 & $74.4^{\mathrm{ab}}$ \\
\hline $5 \%$ & $41.3^{\mathrm{a}}$ & 60.4 & $78.4^{\mathrm{a}}$ \\
\hline Mean of SE & \pm 0.1 & \pm 1.2 & \pm 1.5 \\
\hline Probability & $* *$ & NS & $* *$ \\
\hline \multicolumn{4}{|c|}{ Treatments } \\
\hline Control & $42.9^{\mathrm{a}}$ & $66.7^{\mathrm{a}}$ & $64.4^{\mathrm{d}}$ \\
\hline WB2\% & $41.3^{\mathrm{b}}$ & $63.9^{\mathrm{ab}}$ & $73.9^{\mathrm{bc}}$ \\
\hline WB3\% & $41.5^{\mathrm{b}}$ & $58.7^{\mathrm{bcd}}$ & $67.5^{\mathrm{cd}}$ \\
\hline WB4\% & $40.7^{\mathrm{cd}}$ & $58.4^{\mathrm{cd}}$ & $72.6^{\mathrm{bc}}$ \\
\hline WB5\% & $41.4^{\mathrm{b}}$ & $57.0^{\mathrm{d}}$ & $81.1^{\mathrm{a}}$ \\
\hline BP $2 \%$ & $41.3^{\mathrm{b}}$ & $63.2^{\mathrm{abc}}$ & $76.8^{\mathrm{ab}}$ \\
\hline BP3\% & $41.2^{\mathrm{cb}}$ & $63.4^{\mathrm{abc}}$ & $72.9^{\mathrm{bc}}$ \\
\hline $\mathrm{BP} 4 \%$ & $40.6^{\mathrm{d}}$ & $62.6^{\mathrm{abc}}$ & $76.2^{\mathrm{ab}}$ \\
\hline BP5\% & $41.2^{\mathrm{bc}}$ & $63.8^{\mathrm{ab}}$ & $75.8^{\mathrm{ab}}$ \\
\hline Mean of SE & \pm 0.2 & \pm 1.6 & \pm 2.1 \\
\hline Probability & $* *$ & $* *$ & $* *$ \\
\hline
\end{tabular}


and WB3 recorded 58.4 and 58.7, respectively which were significantly lower compared control. The rest treatments recorded insignificant lower value compared control. On the other hand, all experimental treatments increased blood $\mathrm{O}_{2}$ significantly compared to control except WB3 which showed numerical (nonsignificant) increase, while the highest value was recorded by WB5 (81.1) compared to other treatments.

It is clear that the insignificant change of RR, increased blood $\mathrm{O}_{2}$, and decreased $\mathrm{RT}$ are healthy indicators of the effect of experimental treatments on broiler detected physiological parameters.

All recorded RT were in the normal range according to report of Robertshaw (2004) who showed that the normal rectal temperatures in chickens have a range from 40.6 to $43.0^{\circ} \mathrm{C}$. While Elson (1995) reported cloacal temperatures of 41 and $42^{\circ} \mathrm{C}$ for broilers, comfort conditions. Hypoxia occurs as a result of diminished partial pressure of oxygen, such as occurs with increasing altitude, or reduced oxygen percentage in the air capillaries of the lung (Druyan, 2012). Also, oxygen blood records were in the same range which recorded by Elmenawey et al., (2020) from 74 to $86 \%$.

\section{Economic efficiency:}

The effect of experimental diets on economic efficiency (EE) of broiler production is presented in (Table 11). The calculation based on the price of raw materials in Egyptian market, and the fixed cost and price of one $\mathrm{Kg}$ live weight was calculated as annual averages 19 and $21 \mathrm{LE}$, respectively. The obtained results showed that only WB2 group gained lower EE relative to control EE (97.43), while all treatments improve the relative economic efficiency (REE) of production and the highest REE value recorded by WB5 (245.81). Although, BP5 showed the lower feed cost/bird, the REE (107.03) was decreased as a result of decreased final BW compared with other treatments. The improving in REE by using DD with WB compared BP especially in higher levels 4 and 5\% may be due to the WB having a higher nutritional content and lower fiber content in relation to BP.

Table (11): Effect of experimental treatments on economic efficiency of broiler production

\begin{tabular}{|c|c|c|c|c|c|c|c|c|c|}
\hline Treatment & BW & $\begin{array}{c}\text { Feed } \\
\text { cost/B }\end{array}$ & $\begin{array}{l}\text { Fixed } \\
\text { cost/B }\end{array}$ & $\begin{array}{c}\text { Feed } \\
\text { cost/kg } \\
\text { BW }\end{array}$ & $\begin{array}{c}\text { Relative } \\
\text { FC/kg } \\
\text { BW }\end{array}$ & $\begin{array}{l}\text { Revenue } \\
\text { / Bird }\end{array}$ & $\begin{array}{c}\text { Net } \\
\text { Revenue } \\
\text { (Profit)L.E }\end{array}$ & $\mathrm{EE}$ & REE \\
\hline Control & 2110 & 22.25 & 19 & 10.55 & 100 & 44.3 & 3.05 & 7.40 & 100 \\
\hline WB2 & 2094 & 22.04 & 19 & 10.53 & 99.8 & 44.0 & 2.96 & 7.21 & 97.43 \\
\hline WB3 & 2152 & 21.96 & 19 & 10.20 & 96.7 & 45.2 & 4.24 & 10.35 & 139.86 \\
\hline WB4 & 2227 & 21.96 & 19 & 9.86 & 93.5 & 46.8 & 5.84 & 14.26 & 192.70 \\
\hline WB5 & 2296 & 21.80 & 19 & 9.49 & 90.0 & 48.2 & 7.42 & 18.19 & 245.81 \\
\hline BP2 & 2260 & 22.84 & 19 & 10.10 & 95.8 & 47.5 & 5.66 & 13.53 & 182.84 \\
\hline BP3 & 2171 & 21.52 & 19 & 9.91 & 94.0 & 45.6 & 5.08 & 12.54 & 169.46 \\
\hline BP4 & 2184 & 21.78 & 19 & 9.97 & 94.5 & 45.9 & 5.12 & 12.55 & 169.59 \\
\hline BP5 & 2058 & 21.03 & 19 & 10.22 & 96.9 & 43.2 & 3.17 & 7.92 & 107.03 \\
\hline
\end{tabular}

This results agree with Koschayev et al., (2019) using in 21-41 days, chicken diets replacing by $4 \%$ of dry BP has reduced the feed costs per unit which leads to an increase in profitability by $4.7 \%$. AbouSekken et al., (2013) indicated that dietary the net revenue by increasing dietary BP up to $3 \%$.

\section{CONCLUSION}

In conclusion dilution broiler diet with wheat bran at 3,4 and 5\% and sugar beet pulp at 2, 3 and $4 \%$ improve growth performance, carcass quality, intestine index, economic efficiency, feed coast and REE. Among examined levels the best results recorded by applying 5\% WB and 4\% BP.

It could be recommended WB5\% and BP 4\% were the best enhancer DD treatment of broilers according to the obtained results. 


\section{REFERENCES}

AbouSekken, M .S., S. A.M. Shabban and Randa A. Deifallah (2013). Effect of enzyme supplementation on productive performance of broilers fed diets containing different levels of sugar beet pulp. Egyptian J. Nutrition and Feeds, 16(2): Special Issue: 319-336. Issued by the Egyptian Society of Nutrition and Feeds.

Akhtar, M.; Tariq, A.F.; Awais, M.M.; Iqbal, Z.; Muhammad, F.; Shahid, M.; Hiszczynska-Sawicka, E.(2012). Studies on wheat bran Arabinoxylan for its immunostimulatory and protective effects against avian coccidiosis. Carbohyd. Polym. 90, 333-339.

Apajalahti, J., Kettunen, A. and Graham, H., (2007). Characteristics of the gastrointestinal microbial communities, with special reference to the chicken. World's Poultry Science Journal 60:223-232.

Batal, A.B. and Parsons, C.M., (2002). Effects of Age on Nutrient Digestibility in Chicks fed Different Diets. Poultry Science 81:400-407.

Bautil, A., J. Verspreet, J. Buyse, P. Goos, M. R. Bedford, and C. M. Courtin (2019). Age-related arabinoxylan hydrolysis and fermentation in the astrointestinal tract of broiler fed wheatbased diets. Poult. Sci. 98:4606-4621.

Bautil, A.;J. Verspreet,J.Buyse,P. Goos,M. R. Bedford,and C. M. Courtin(2020). Arabinoxylanoligosaccharides kick-start arabinoxylan digestion in the aging broiler. Poultry Science.Volume 99, Issue 5, Pages 2555-2565.

De Mora Ruiz-Roso, B.C. (2015). Positive effects of wheat bran for digestive health; Scientific evidence. NutriciónHospitalaria. 32, 41-45.

Diao,H.; Anran Jiao, Bing Yu, Jun He, Ping Zheng, Jie Yu, YuhengLuo,Junqiu Luo, Xiangbing Mao and Daiwen Chen (2020). Beet Pulp: An Alternative to Improve the Gut Health of Growing Pigs. Animals. $10(10), 1860$ (1-16).

Druyan S, (2012). Ascites Syndrome in Broiler Chickens - A Physiological Syndrome Affected by Red Blood Cells. "Blood Cell-An Overview of Studies in Hematology", Ed. by Terry E. Moschandreou, ISBN 978-953-51-0753-8, Published: September 21, 2012. Chapter 13.

Duncan, D. B. (1955). Multiple range and multiple F-testes. Biometrics, 11: 1-42.

Elmenawey MA, Faten A Mohammed, Eman A Morsy, GA Abdel-Alim and MHH Awaad (2020). The Impact of Essential Oils Blend on Experimental Colisepticemia in Broiler Chickens. International journal of veterinary Science, 8(4): 294-299.

Elson, H.A., (1995). Environmental factors and reproduction. (AUSTIC, R.; NESHEIM, M.C Eds). Poultry production, Philadelphia; Lea and Febiger, pp 389-409.

González-Alvarado, J.M.; E. Jiménez-Moreno; R. Gonzalez-Sanchez;R. Lázaro and G.G. Mateos (2010). Effect of inclusion of oat hulls and sugar beet pulp in the diet on productive performance and digestive traits of broilers from 1 to 42 days of age. J. Animal Feed Science and Technology.162: 37 46.

Gonzalez-Alvarado, J.M.; E. Jiménez-Moreno; R. Lgzaro and G.G. Mateos (2007). Effect of type of cereal, heat processing of the cereal, and inclusion of fiber in the diet on productive performance and digestive traits of broilers. Poult. Sci. 86, 1705-1715.

Jimenez-Moreno, E.; J. M. Gonzalez-Alvarado; A. de Coca-Sinova; R. Lazaro, and G. G. Mateos (2009a). Effects of source of fiber on the development and $\mathrm{pH}$ of the gastrointestinal tract of broilers. Anim. Feed Sci.Technol154:93-101.

Jimenez-Moreno. E; J.M. Gonzalez-Alvarado; A. Gonzalez- Serrano; R. Lazaro and G.G. Mateos. (2009b). Effect of dietary fiber and fat on performance and digestive traits of broilers from one to twenty-one days of age.J. Poult. Sci. 88:2562-2574.

Kamal-Eldin, A.; Lærke, H.N.; Knudsen, K.B.; Lampi, A.; Piironen,V.; Adlercreutz, H.; Katina, K.; Poutanen, K.;Åman, P.(2009). Physical, microscopic and chemical characterisation of industrial rye and wheat brans from theNordic countries. Food Nutr. Res. 2009, 53, 1912. 
Kheravii , S.K. , N.K. Morgan , R.A. Swick , M. Choct and S.B. Wu. (2018).Roles of dietary fiber and ingredient particle size in broiler nutrition. World's Poultry Science Association. Volume74 issue 2 June.

Koschayev, I.; Ivan Boiko; SvetlanaKornienko ; Olga Tatiyanicheva ; Oleg Sein ; Svetlana Zdanovich ; Oksana Popova (2019). Feeding Efficiency of Dry Beet Pulp to Broiler Chickens. Advances in Biological Sciences Research, volume 7.1st International Symposium Innovations in Life Sciences (ISILS 2019).pp:167-170.

Lee, S. A., J. Apajalahti, K. Vienola, G. Gonz_alez-Ortiz, C. M. G. A. Fontes, and M. R. Bedford,(2017). Age and dietary xylanase supplementation affects ileal sugar residues and short chain fatty acid concentration in the ileum and caecum of broiler chickens. Anim. Feed Sci. Technol. 234:29-42.

Liu, G.; Xiao, L.; Fang, T.; Cai, Y.; Jia, G.; Zhao, H.; Wang, J.; Chen, X.; Wu, C. (2014). Pea fiber and wheat branfiber show distinct metabolic profiles in rats as investigated by a $1 \mathrm{H}$ NMR-based metabolomic approach.PLoS ONE 9, e115561.

Masey O'Neill, H.V., Liu, N., Wang, J.P., Diallo, A. and Hill, S., (2012). Effect of xylanase on performance and apparent metabolisable energy in starter broilers fed diets containing one maize variety harvested in different regions of china. Asian-Australasian Journal of Animal Sciences 25:515523.

Mateos, G. G., R. Lázaro, and M. I. Gracia. (2002). The feasibility of using nutritional modifications to replace drugs in poultry feeds. J.Appl. Poult. Res. 11:437-452.

Nir, I., Z. Nitsan, E. A. Dunington and P. B. Siegel (1996). Aspects of food intake restriction in young domestic fowl: Metabolic and Genetic consideration. World's Poul. Sci. 52: 251-266.

Noy, Y., and D. Sklan (2002). Nutrient use in chicks during the first week post hatch. Poultry. Sci. 81, 391- 399.

NRC (1994). Nutrient Requirements of Poultry: Ninth Revised Edition, 1994.

Nyman M, Schweizer TF, Tyre'n S, Reimann S, Asp NG (1990). Fermentation of vegetable fiber in theintestinal tract of rats and effects on fecal bulking and bile acid excretion. J Nutr 120: 459-466.

Pan, D. and Yu, Z., (2014). Intestinal microbiome of poultry and its interaction with host and diet. Gut Microbes 5:108-119.

RCFF; Regional Center for Food and Feed (2001). Feed Composition Tables For Animal and Poultry Feedstuffs Used In Egypt, Technical Bulletin, No.1, Ministry of Agriculture, Egypt.

Rehman, H.U., Vahjen, W., Awad, W.A. and Zentek, J., (2007). Indigenous bacteria and bacterial metabolic products in the gastrointestinal tract of broiler chickens. Archives of Animal Nutrition 61:319-335.

Robertshaw, D.,(2004). Temperature Regulation and Thermal Environment in Dukes. Physiology of Domestic Animals 12th Edition, Reece W.O, Edition. Copyright 2004 by Cornell University.

Sahraei M. and Shariatmadari F. (2007). Effect of Different levels of diet dilution during finisher period on broiler chickens performance and characteristics. International Journal of Poultry Science 6 (4): 280-282.

SAS (2001). User's Guide: Statistics. Version 8.2, Cary, NC, USA.

Shang, Q., Di Wu, Hansuo Liu, Shad Mahfuz and XiangshuPiao (2020). The Impact of Wheat Bran on the Morphology and Physiology of the Gastrointestinal Tract in Broiler Chickens. Animals. 10(10), 1831(1-12).

Van Der Sluis, W., (1999). The broiler for next century. World Poult. 15: 28-30.

Vermeulen, K., (2017). Wheat bran with reduced particle size as carrier for microbial networks that affect salmonella colonization. PhD thesis, Ghent University, Belgium:p. 212.

Zubari, A. K. and S. Leeson, (1996).Compensatory growth in broiler chicken: a review. World's Poult. Sci., 52: 189-201. 
تقيم تخفيف العليقة بمصادر ومستويات مختلفه علي الأداء الاتتاجي وجودة الذبيحه لكتاكيت التسمين.

همت عبدالعال عبدالمجيد و مني عبدالله سبد أحمد مصطفي² و محمد عبدالرحمن المناوي3 3

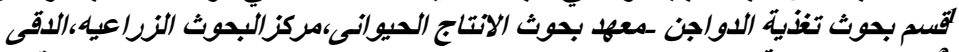

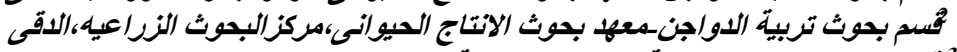

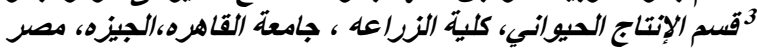

تهدف الدراسة الي تقييم تأثير إستخدام نخالة القمح (WB) وتفل بنجر السكر(BP) كمصادر علفيه قليلة الكثافة علي أداء دجاج

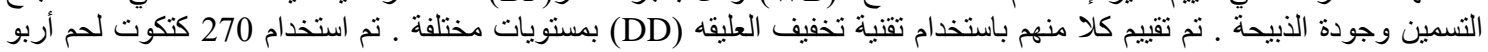

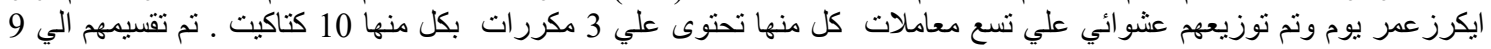

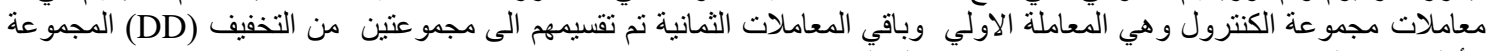

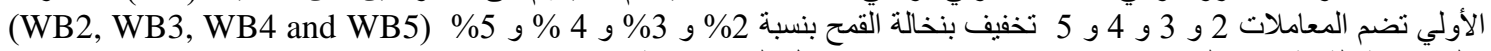

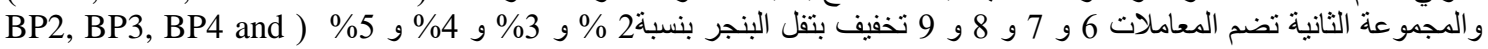

(BP5

أظهرت النتائج ان التخفيف بنخالة القصح خلال مراحل البادي والناهي والمتوسط النهائي للفترة حقق فرق معنوي في وزن الجسم

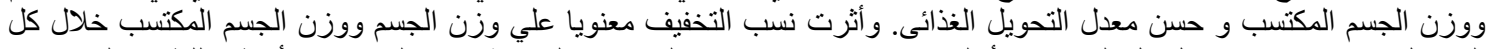

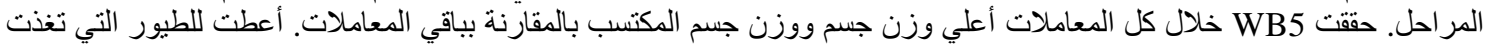

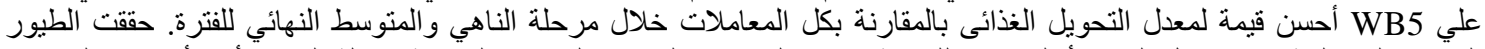

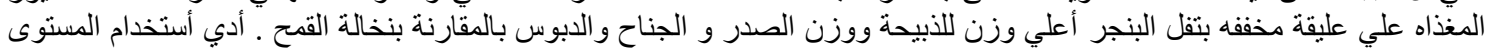

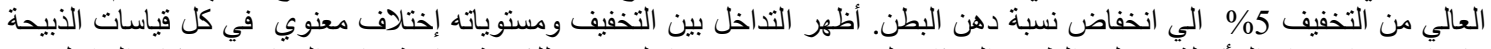

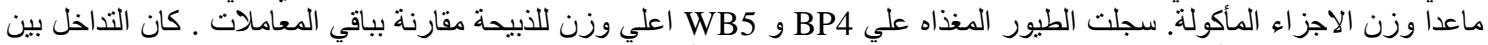

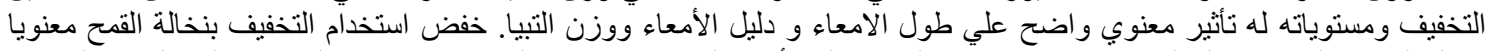

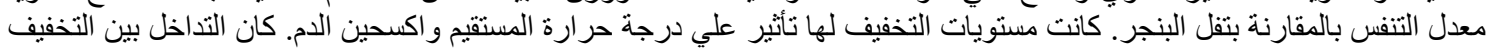

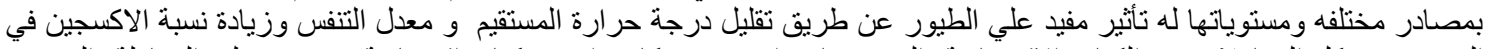

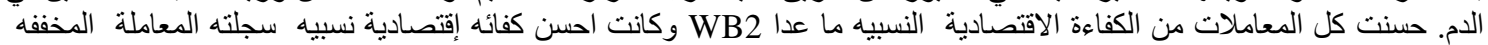
بنخالة القمح بنسبة 5\% (WB5)

نستخلص من ذلك ان تخفيف علائق الدو اجن بنخالة القمح بنسبة3 و 4 و 5 و و وتفل البنجر بنسبة 2 و 3 و و 4 \% كان له تأثير مفيد

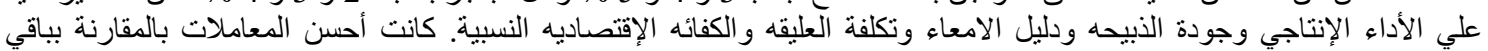
المعاملات هما معامله التخفيف بمستوى 4\% لتفل البنجر ومعاملة التخفيف بمستوي 5\% لنفالة النالة القمح. 